Vol. 3, No 1, Juni 2020

Hal 89-100

\title{
PEMETAAN POLA SEBARAN SAMPAH BERDASARKAN JENIS DI WILAYAH PESISIR PANTAI KURI KABUPATEN MAROS SULAWESI SELATAN
}

\section{(Mapping Pattern of Garbage Distribution by Type on the Kuri Coastal Coast of Maros Regency)}

\author{
Rahayu Abriani Sahar 1), Abd. Rauf 2) dan Hamsiah 2) \\ 1) Mahasiswa Pascasarjana Universitas Muslim Indonesia \\ 2) Dosen Program Studi Manajemen Pesisir dan Teknologi Kelautan, \\ Pascasarjana Universitas Muslim Indonesia \\ Korespondensi:rahayusahar05@gmail.com
}

Diterima: tanggal 1 Maret 2020; Disetujui 5 April 2019

\begin{abstract}
Mapping Pattern of Garbage Distribution by Type on the Kuri Coastal Coast of Maros Regency. This study aimed to identify and map the pattern of waste distribution based on the type and size of the Kuri coast and formulate a strategy for managing the distribution of waste patterns on the Kuri coast. The method used in this study is a questionnaire distribution method (questionnaire) carried out by way of giving questionnaires to the respondents, identification of waste, mapping using GPS and SWOT analysis to determine the direction of the strategy. The most dominant type of waste in each location was soft plastic waste with a percentage of $40.51 \%$ and based on a map of the distribution of marine garbage collection points in 2019 in the Kuri Caddi Hamlet, it is known that almost all over the coast bordering the sea contributes to the pollution of marine trash, especially rubbish Plastic. The direction of the management strategy was the first priority, namely : 1) Preparation and enforcement of waste management regulations in the form of PERDA or regulations covering sorting from prohibited sources and sanctions, 2) Oversight of oceanic waste reaching the shore and which will settle in waters and Assistance in the activities of garbage banks and composting.
\end{abstract}

\section{Keywords: Distribution Pattern, Marine Trash, Mapping, SWOT}

\section{ABSTRAK}

Pemetaan Pola Sebaran Sampah Berdasarkan Jenis di Pesisir Pantai Kuri Kabupaten Maros. Penelitian ini bertujuan untuk mengidentifikasi dan memetakan pola sebaran sampah berdasarkan jenis dan ukuran di pesisir pantai Kuri dan merumuskan strategi pengelolaan pola sebaran sampah di pesisir pantai Kuri. Metode yang digunakan dalam penelitian ini adalah metode penyebaran angket (kuesioner) dilakukan dengan jalan dan memberikan kuesioner kepada para responden, identifikasi sampah,pemetaan dengan menggunakan GPS serta analisis SWOT untuk penentuan arahan strategi. Jenis sampah yang paling dominan di setiap lokasi adalah sampah plastik lunak dengan persentase 40,51 \% dan bedasarkan peta sebaran titik kumpul sampah laut tahun 2019 di Dusun Kuri Caddi, diketahui hampir diseluruh di pesisir pantai yang berbatasan dengan laut berkontribusi terhadap pencemaran sampah laut terutama sampah plastik. Arahan strategi pengelolaan yang menjadi prioritas utama yaitu, 1) Penyusunan dan penegakan peraturan pengelolaan sampah berupa PERDA atau peraturan yang meliputi pemilahan dari sumber larangan serta sanksi, 2) Pengawasan sampah lautan yang sampai di pantai dan yang akan mengendap di perairan dan Pendampingan dalam kegiatan bank sampah dan pengomposan.

Kata kunci: Pola Sebaran, Sampah Laut, Pemetaan, SWOT 


\section{PENDAHULUAN}

Indonesia sebagai negara maritim saat ini sedang mengalami kasus pencemaran laut. Pencemaran tersebut berasal dari berbagai sumber yaitu pencemaran yang berasal dari daratan, pencemaran berasal dari aktifitas dasar laut, pencemaran dari pembuangan limbah (dumping), pencemaran dari kapal laut, dan pencemaran dari atau melalui atmosfer. Salah satu yang dapat mengubah kualitas perairan adalah adanya sampah laut yang di akibatkan oleh kegiatan antropogenik (Hetherington, et al, 2005). Berbagai masalah muncul akibat adanya sampah laut (marine debris) yaitu materi padatan mengapung di permukaan laut yang bersifat persisten yang diproduksi atau diproses oleh manusia, secara langsung atau tidak langsung, sengaja atau tidak sengaja, dibuang atau ditinggalkan di dalam lingkungan laut yang berdampak berkurangnya keindahan wilayah pesisir, menimbulkan berbagai macam penyakit, mempengaruhi jejaring makanan, berkurangnya produktivitas sumber daya ikan serta dapat mempengaruhi keseimbangan ekosistem di wilayah pesisir. Bila hal menjadikan sebagai bahan informasi tersebut terjadi dan terus berlangsung dan wawasan mengenai dampak dari maka berpengaruh terhadap rantai makanan, perekonomian dan kesehatan masyarakat di daerah tersebut tidak dapat di hindari (Citasari, et al., 2012).

Penelitian ini dilakukan dikarenakan melihat kondisi pesisir pantai kuri terdapat banyak jenis sampah dan lebih cenderung adalah sampah plastik. Dilihat sebagian pesisir pantai kuri berupa batuan, maka banyak sampah yang tersangkut pada celah batu yang di bawa oleh arus. Banyaknya pemukiman di sekitar pantai kuri bisa menjadi salah satu faktor banyaknya dan bertambahnya sampah di wilayah tersebut. Berdasarkan yang telah diuraikan diatas sangat perlu dilakukan pemetaan pola sebaran dan identifikasi sampah laut (marine debris) berdasarkan jenis pada saat pasang dan surut serta strategi pengelolaan sampah di daerah Pesisir Pantai Kuri caddi, Kabupaten Maros. Penelitian bertujuan untuk mengidentifikasi dan memetakan pola sebaran sampah berdasarkan jenis dan ukuran di Pesisir Pantai Kuri serta merumuskan strategi pengelolaan pola sebaran sampah di sekitar Pesisir Pantai Kuri. Penelitian ini di harapkan dapat can wawasan mengenai dampak dari 
sampah pesisir dan pengelolaan sampah dalam upaya pelestarian wilayah tersebut.

\section{MATERI DAN METODE}

Penelitian ini dilakukan pada sebaran sampah.
2019 di daerah pesisir Pantai Kuri Kabupaten Maros Sulawesi Selatan. Penelitian ini juga menggunakan metode tracking untuk mengetahui pola tanggal 31 Agustus - 30 September

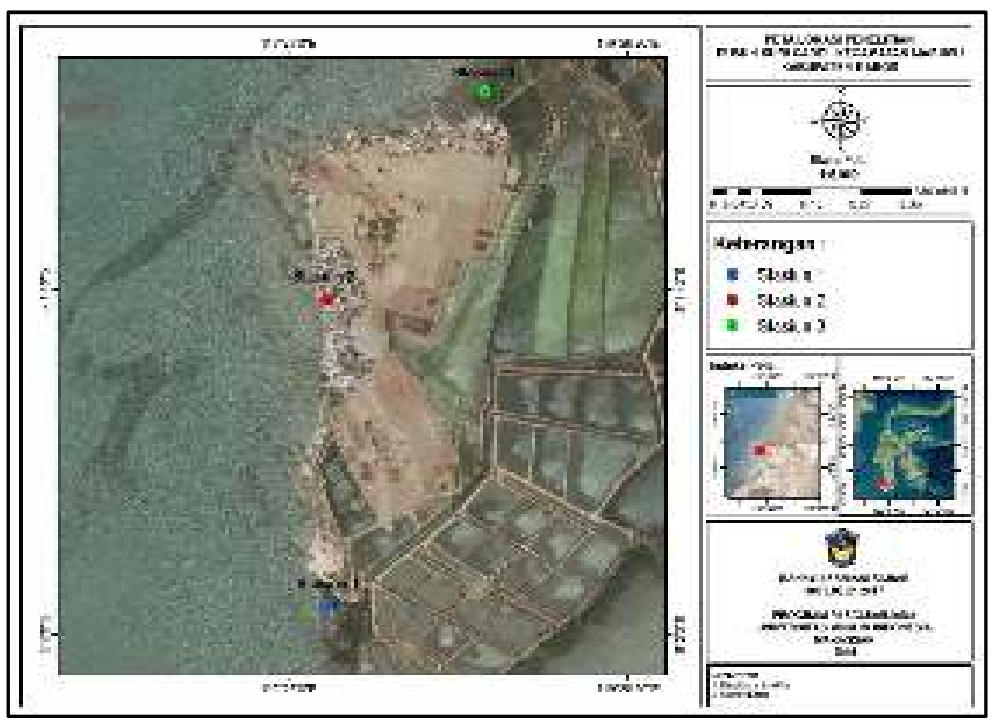

Gambar 1. Peta Lokasi Penelitian

Alat yang digunakan antara lain: penelitian yang menggunakan alat alat tulis untuk menulis data sampah, pengukuran atau alat pengambilan data kamera di gunakan untuk dokumentasi, langsung pada subyek sebagai sarung tangan di gunakan pada saat informasi yang di cari. Sedangakan mengambil sampah, stopwatch untuk data sekunder yaitu data yang diperoleh mengukur waktu, layangan arus untuk dari pihak lain, tidak langsung dari mengukur arus,tiang skala digunakan subyek penelitiannya (Azwar, 1999). untuk mengukur gelombang. Adapun bahan yang digunakan yaitu kantong sampah, sampel sampah untuk di karakteristikan berdasarkan ukuran. Jenis data yang digunakan dalam memberikan kuesioner kepada para penelitian ini yaitu data primer dan data responden, dan juga melakukan sekunder. Data primer adalah data yang observasi. Adapun prosedur seperti di peroleh secara langsung dari subyek berikut:
Teknik pengambilan data yang akan digunakan dalam penelitian ini adalah metode penyebaran angket (kuesioner) dilakukan dengan jalan dan 


\section{- Tahap Persiapan}

Pada tahap persiapan terbagi menjadi studi pustaka yang berkaitan dengan judul penelitian, penentuan metode penelitian, survey lapangan, pengumpulan alat dan bahan yang digunakan selama penelitian.

- Penentuan Lokasi Penelitian dan Titik Pengambilan Sampel

Penentuan lokasi penelitian, Ukuran sampah yang diamati memiliki terlebih dahulu mengecek jadwal ukuran $>2,5 \mathrm{~cm}$ atau termasuk dalam pasang surut perairan, hal ini sesuai ukuran sampah makro. Setelah dengan pendapat Opfer et al.(2012), pengumpulan sampah, dilakukan bahwa tinggi rendahnya permukaan air pemisahan berdasarkan Jenisnya, lalu (pasang surut) yang terjadi akan ditimbang dengan menggunakan mempengaruhi volume/jumlah sampah portable electronic scale. Setelah itu yang terdapat pada suatu daerah pesisir. semua sampah diukur menggunakan Selain itu, penentuan transek penggaris kemudian disortir pengambilan sampah laut berdasarkan berdasarkan jenis ukuran yang pada panjang garis pantai, hal ini untuk dikemukakan oleh Lippiat et al, (2013). mengetahui bentang alam sehingga dalam penentuan transek mewakili seluruh lokasi penelitian.

\section{- Pengambilan Sampah Laut}

dilakukan dengan metode transek garis (line transek) untuk mengetahui jenis dan jumlah. Pengambilan sampel dalam transek dengan lebar 1 meter kekiri dan 1 meter kekanan untuk panjang transek di bentangkan sepanjang 20 meter .

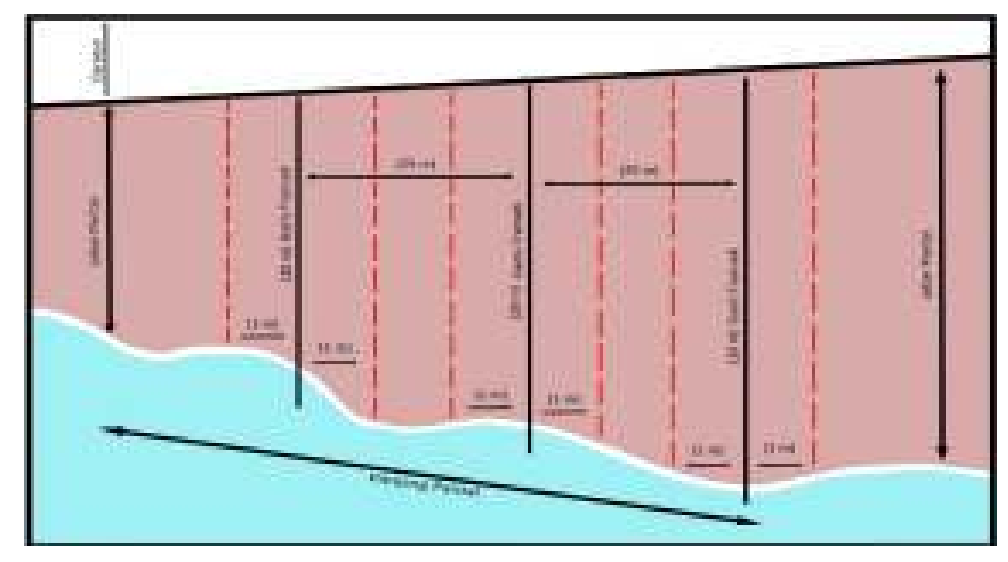

Gambar 2. Penentuan Stasiun 
- Teknik Identifikasi Sampah Positioning System (GPS), kemudian

\section{Berdasarkan Jenis Sampah}

Sampah laut di tepi pantai adalah sampah laut yang terdeposit di pantai karena terbawa arus atau ombak air laut. Pengamatan dilakukan pada saat air laut surut terendah di daerah intertidal. Sampah yang ditemukan disetiap interval panjang transek dikumpulkan lalu dicatat menurut jenisnya di form items list dan sampah yang pertama kali ditemukan dicatat dan diukur ukurannya dengan menggunakan debris size chart. Untuk mendapatkan interval, panjang transek, 20m dibagi dengan 10. Sampel sampah laut yang sudah terkumpul pada masing-masing plot di dokumentasikan dan dimasukkan kedalam trashbag.

- Pemetaan Sebaran Sampah Laut

Penelitian ini dilakukan dengan cara pengamatan langsung pada lokasi tempat penelitian yaitu Dusun Kuri Caddi serta dengan melakukan pencatatan dokumen yang berkaitan dengan obyek penelitian, yaitu persebaran sampah laut yang ada di Dusun Kuri Caddi. Rancangan penelitian yang digunakan pada penelitian ini adalah survey deskriptif yang diperkuat dengan hasil pemetaan dengan menggunakan Global diolah dengan menggunakan sistem informasi geografi untuk mengetahui dan menggambarkan lokasi sebaran sampah laut di Dusun Kuri Caddi.

\section{- Pengukuran}

parameter oseanografi

Nybakken (1992) menyatakan bahwa oseanografi ialah suatu disiplin ilmu yang mengkhususkan diri dalam pengkajian segala aspek fisika, kimia, geologi, dan biologi di laut. Distribusi sampah laut dapat terjadi di perairan dikarenakan adanya faktor fisik yang membawa sampah dari satu lokasi ke lokasi yang lain. Adapun parameter oseanografi yang diukur yaitu :

a) Kecepatan arus

Kecepatan arus diukur dengan menggunakan laying-layang arus. Layangan arus dibiarkan terbawa arus hingga tali lurus, setelah itu mencatat waktu tempuh sepanjang 10 meter dan di bidik dengan menggunakan kompas searah dengan tali untuk menentukan arah arus.

\section{b) Gelombang}

Pengukuran gelombang dilakukan dengan mengukur puncak dan lembah setiap 2 jam selama 12 jam pada tiang skala. Selama pengukuran dihitung waktunya dengan menggunakan 
stopwatch. Selain itu arah datang gelombang juga dilihat dengan menggunakan kompas. Pengukuran gelombang dilakukan 7 kali pada waktu-waktu $06.00, \quad 08.00, \quad 10.00$, 12.00, 14.00, 16.00, 18.00 .

c) Pasang Surut

Pengukuran ini dilakukan dengan tiang skala/rambu ukur yang ditempatkan di tempat yang mudah dijangkau dimana pada kondisi surut tempat tersebutmasih tergenang oleh air laut.

\section{- Analisis data}

a.) Arus

$$
\mathrm{V}=\mathrm{S} / \mathrm{t}
$$

Keterangan :

$\mathrm{V}=$ Kecepatan arus (m/detik)

$\mathrm{S}=$ Jarak tempuh

$\mathrm{T}=$ Waktu yang digunakan /detik

b.) Gelombang

- $\quad$ Tinggi ombak $\mathrm{H}=$ (Puncak ombak lembah ombak)

- Tinggi ombak signifikan $\left(\mathrm{H}_{1 / 3}\right)$

$$
\mathrm{H}_{1 / 3}=1 / 3 \text { rata-rata dari }
$$
gelombang terbesar

- Periode ombak (T)

$$
\mathbf{T}=\mathbf{t} / \mathbf{n}
$$

Keterangan :

$$
\mathrm{H} \quad=\text { Tinggi ombak }
$$

(m)

$\mathrm{H} 1 / 3$ = Tinggi ombak signifikan (m)

$\mathrm{T}=$ Periode

gelombang

$(\mathrm{s}) \mathrm{t}=$ Waktu pengamatan

(s) $\mathrm{n}=$ Banyaknya gelombang

\section{c.) Pasang surut}

Pengukuran pasang surut di lakukan setiap 60 menit, dengan tinggi air di ukur dengan menggunakan kayu yang telah berskala dan pada titik yang sama di mulai pada pukul 20:00 s/d 20:00 wib, Kemudian di catat ketinggian air tertinggi dan air terendah, yang kemudian akan di buatkan dalam bentuk tabel.

d) Analisis Spasial

Pengolahan data pola sebaran sampah ini di lakukan dengan metode pemetaan menggunakan Tracking dengan media pendukung GPS.

b) Arahan Strategi Pengelolaan

Berdasarkan hasil analisa sebelumnya selanjutnya dilakukan analisis SWOT (Strength, Weaknes, Opportuniy and Theart). Analisis 
SWOT digunakan untuk merumuskan satudusun dengan Kuri Caddi. Untuk strategi rehabilitasi mangrove, bersifat menuju ke Dusun Kuri Caddi dapat kualitatif dengan melakukan ditempuh dengan dua jaluryang identifikasi secara sistematis terhadap pertama jalur darat, biasanya lewat berbagai faktor yang melingkupinya. pintu merah istilah untuk warga

Analisis didasarkan pada logika setempat yang terdapat di Dusun Kuri yang dapat memaksimalkan kekuatan Lompo dengan kondisi jalan yang (strength) dan peluang (opportunities), begitu bergelombang, berbatu, kadang namun secara bersamaan dapat becek, berlumpur, bahkan beberapa meminimalkan kelemahan (weakness) jalannya harus menyebrangi jembatan. dan ancaman (threats). Dengan Jalur yang kedua adalah lewat laut. Di demikian perencana strategis harus lokasi ini banyak terdapat tambak menganalisis faktor-faktor strategis terlantar yang dimanfaatkan oleh yang ada (kekuatan, kelemahan, masyarakat sebagai areal wisata untuk peluang dan ancaman) dalam kondisi memancing ikan.

yang ada pada saat ini. Adapun langkah-langkah yang dilakukan dalam analisis SWOT (Strength, Weaknes, Jenis dan Jumlah Sampah Menurut Renwarin, et al (2002), Opportuniy and Theart) adalah sebagai jenis-jenis sampah terbagi menjadi : berikut: (1) Identifikasi Kekuatan, sampah organik terdiri dari bahanKelemahan, Peluang dan Ancaman; (2) bahan penyusun tumbuhan dan hewan Analisis SWOT; (3) Arahan Strategi yang diambil dari alam atau dihasilkan Pengelolaan Hasil Analisa SWOT dari kegiatan pertanian, perikanan dan lainnya. Sampah ini dengan mudah

\section{HASIL DAN PEMBAHASAN}

Kuri Caddi merupakan salah satu dusun pesisir dari empat dusun yang terdapat di Desa Nisombalia, Kecamatan Marusu, Kabupaten Maros. Ketiga dusun lainnya adalah Dusun Tala-tala, Mambue dan Dusun Kuri Lompo yang dulunya merupakan diuraikan dengan proses alami. Adapun jenis sampah yang dikumpulkan di sekitar pesisir pantai kuri terdiri atas 13 kategori jenis umum berdasarkan form CSIRO. Pada Tabel 1 menunjukkan jenis dan jumlah sampah laut yang ditemukan saat penelitian. 
Tabel 1. Jumlah Setiap Jenis Sampah di pesisir pantai kuri

\begin{tabular}{clcccc}
\hline No. & Jenis Sampah & Pecahan & Utuh & Total & Persentase \\
\hline 1 & Plastik Keras & 261 & 322 & 583 & 12,62 \\
2 & Plastik Lunak & 1088 & 784 & 1872 & 40,51 \\
3 & Tali Plastik & 74 & 14 & 88 & 1,90 \\
4 & Logam & 37 & 24 & 61 & 1,32 \\
5 & Kaca & 121 & 40 & 161 & 3,48 \\
6 & Karet & 79 & 24 & 103 & 2,23 \\
7 & Busa & 523 & 21 & 544 & 11,77 \\
8 & Kain & 60 & 14 & 74 & 1,60 \\
9 & Kayu & 508 & 5 & 513 & 11,10 \\
10 & Kertas/Kardus & 332 & 209 & 541 & 11,71 \\
11 & Lain-lain & 61 & 20 & 81 & 1,753 \\
\hline \multicolumn{2}{r}{ Total } & $\mathbf{3 1 4 4}$ & $\mathbf{1 4 7 7}$ & $\mathbf{4 6 2 1}$ & $\mathbf{1 0 0}$ \\
\hline
\end{tabular}

Sampah plastik merupakan jenis jenis yang paling umum dan banyak sampah yang mudah mengapung dan dijumpai serta yang paling beresiko terbawa oleh arus perairan dan teraduk memberikan dampak pada organisme oleh gelombang, sehingga sangat laut.

memungkinkan untuk menjadikan - Peta Sebaran dan Jumlah Sampah sampah ini sebagai sampah dengan Rancangan penelitian yang akumulasi terbanyak di perairan. digunakan pada penelitian ini adalah Plastik merupakan konsumsi umum survey deskriptif yang diperkuat bagi masyarakat modern, sebagian dengan hasil pemetaan dengan besar konsumsi plastic hanya menggunakan Global Positioning digunakan sekali. Akibatnya tumpukan System (GPS), kemudian diolah dengan sampah plastic akan mencemari menggunakan sistem informasi lingkungan dan laut (Wang. et al, geografi untuk mengetahui dan 2016). Hal yang senada telah menggambarkan lokasi sebaran sampah dilaporkan oleh NOAA (2016) bahwa laut di Dusun Kuri Caddi.

hasil penelitian mengenai sampah laut Berikut peta sebaran sampah laut yang terdapat di seluruh perairan di yang berada di Dusun Kuri caddi yang dunia, jenis sampah plastik merupakan disajikan pada gambar dibawah ini : 


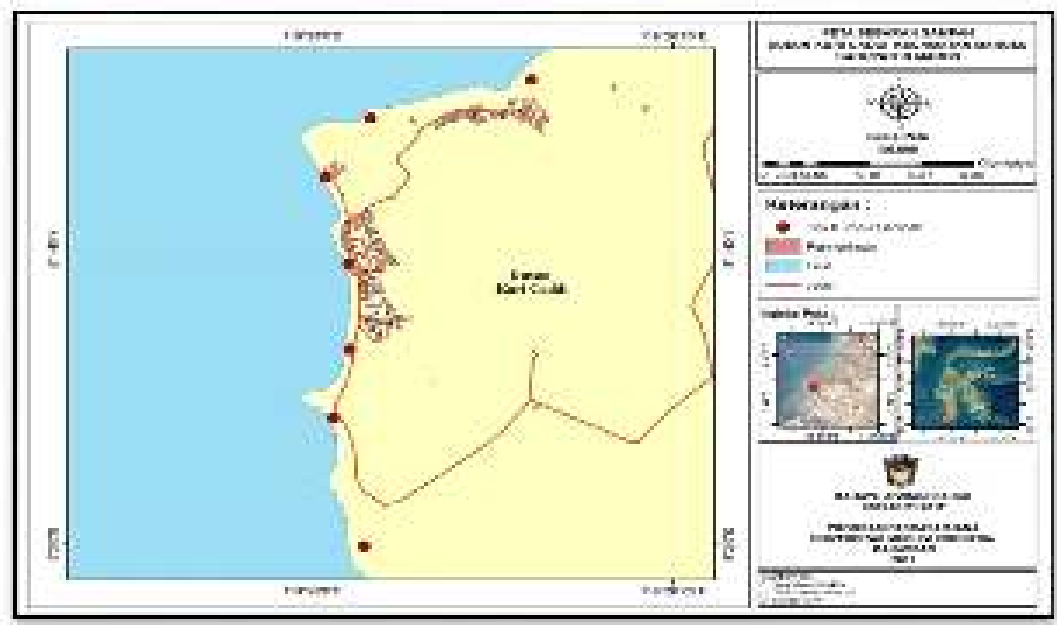

Gambar 3. Peta Titik Kumpul Sampah

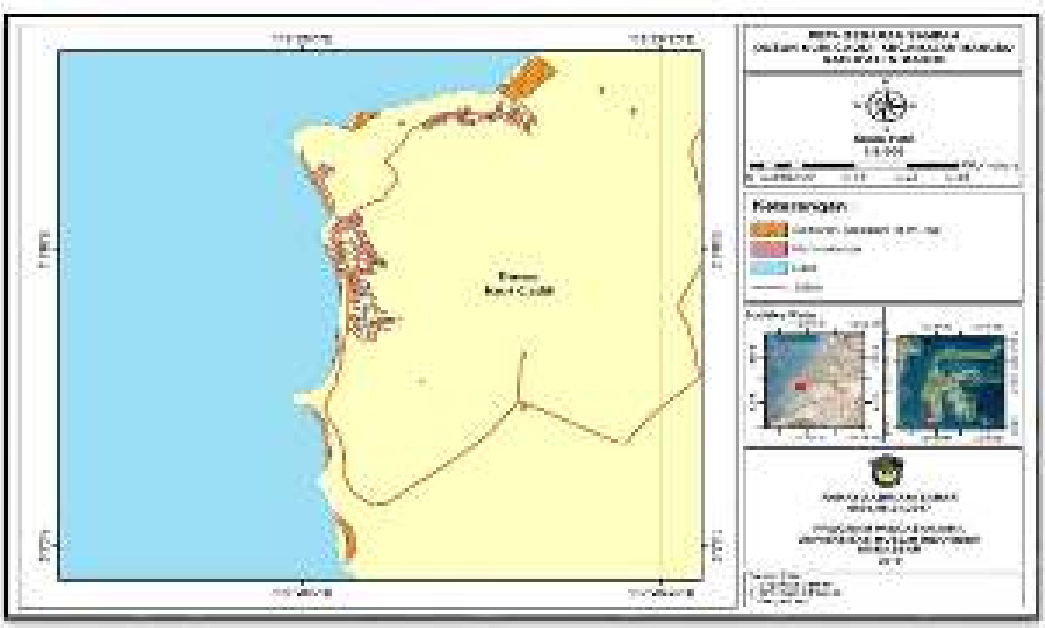

Gambar 4. Peta Sebaran Sampah Laut di Dusun Kuri Caddi

Pada gambar diatas bisa diketahui perpindahan sampah laut di perairan bahwa hampir disuluruh pesisir pantai dengan jarak yang cukup jauh. Arus Dusun Kuri Caddi menjadi tempat merupakan pergerakan massa air laut berkumpulnya sampah laut. Luasan yang diakibatkan oleh adanya tiupan sebaran sampah pada saat penelitian angin yang berhembus di permukaan adalah sebesar 0,94 ha dan sampah air laut atau dapat juga disebabkan oleh plastik merupakan sampah yang gerakan gelombang yang panjang atau dominan dijumpai di seluruh pesisir disebabkan oleh pasang surut pantai Dusun Kuri Caddi. Menurut (Nontji,1987).

NOAA (2016) arus merupakan salah Data mengenai timbulan, satu faktor yang mendukung komposisi, dan karakteristik sampah 
merupakan hal yang sangat menunjang dalam menyusun sistem pengelolaan persampahan di suatu wilayah. Jumlah timbulan sampah ini biasanya akan berhubungan denga eleman-elemen pengelolaan seperti : Pemilihan peralatan, misalnya wadah dan alat, Pengumpulan dan pengangkutan, Perencanaan rute pengangkutan, serta fasilitas untuk daur ulang luas dan jenis TPA.

Sampah laut (marine debris) merupakan bahan padat yang diproduksi atau diproses secara langsung atau tidak langsung, sengaja atau tidak sengaja, dibuang atau ditinggalkan dalam lingkungan laut (CSIRO, 2014).

\section{- Strategi Pengelolaan Sampah Laut}

Formulasi strategi pengelolaan sampah memerlukan suatu proses analisis secara multidimensi dengan mengakomodir semua aspek yang berkaitan dengan pengelolaan sampah secara strategis. Arahan pengelolaan sampah di susun berdasarkan atau mempertimbangkan dimensi pembangunan berkelanjutan. Unsur KESIMPULAN kekuatan (Strength) antara lain : Sampah lautan dominan plastik kemasan dan Sampah rumah tangga dominan organic. Unsur kelemahan
(Weakness) antara lain : Kebiasaan masyarakat membuang sampah di laut, Tidak ada denda apabila masyarakat membuang sampah di laut, Tingkat pendidikan rendah, Masyarakat setuju mengelola sampah jika ada uang, serta Bank sampah tidak beradaptasi. Unsur peluang (Opportunity) antara lain : Daur ulang sampah plastic, Program sampah ditukar beras, Pengadaan kapal angkut sampah, serta Pengomposan sampah. Unsur ancaman (Threat) antara lain : Sampah kiriman yang datang terbawa arus dan Kurangnya SDM untuk pengelola sampah. Ada dua Arahan strategi pengelolaan yang menjadi prioritas utama yaitu, 1) Penyusunan dan penegakan peraturan pengelolaan sampah berupa PERDA atau peraturan yang meliputi pemilahan dari sumber larangan serta sanksi, 2) Pengawasan sampah lautan yang sampai di pantai dan yang akan mengendap di perairan dan Pendampingan dalam kegiatan bank sampah dan pengomposan

1. Jenis sampah yang paling dominan di setiap lokasi adalah sampah plastik lunak dengan persentase $40,51 \%$ dan bedasarkan peta sebaran 
sampah laut tahun 2019 di Dusun Kuri Caddi, luas sebaran sampah laut pada saat penelitian adalah sebesar $0,94 \mathrm{Ha}$ dan diketahui hampir diseluruh di pesisir pantai yang berbatasan dengan laut berkontribusi terhadap pencemaran sampah laut terutama sampah plastik.

2. Arahan strategi pengelolaan yang menjadi prioritas utama yaitu, 1) Penyusunan dan penegakan peraturan pengelolaan sampah berupa PERDA atau peraturan yang meliputi pemilahan dari sumber larangan serta sanksi, 2) Pengawasan sampah lautan yang sampai di pantai dan yang akan mengendap di perairan dan Pendampingan dalam kegiatan bank sampah dan pengomposan

\section{SARAN}

Penelitian mengenai jenis sampah

di Dusun Kuri Caddi sebaiknya dilakukan penelitian lebih lanjut mengenai dampak secara fisiologis terhadap organisme yang terdapat di ekosistem dengan pemaparan sampah secara langsung. Serta, perlu adanya keterlibatan dan kesadaraan masyarakat setempat dan pemerintah setempat untuk menanggulangi dan mengolah banyaknya sampah yang ada di Dusun Kuri Caddi.

\section{UCAPAN TERIMA KASIH}

Tulisan ini merupakan bagian dari penelitian Tesis dan penulis mengucapkan terima kasih kepada Ketua Prodi Manajemen Pesisir dan Teknologi Kelautan dan Direktur Pasca Sarjana yang telah memberi kesempatan untuk melanjutkan pendidikan di Program Pascasarjana Universitas Muslim Indonesia

Makassar.

\section{DAFTAR PUSTAKA}

Azwar, S. 1999. Metode Penelitian. Pustaka Pelajar. Yogyakarta

Citasari, N, Nur IO, dan Nuril A., 2012. Analisis Laju Timbunan dan Komposisi Sampah di Permukiman Pesisir Kenjeran Surabaya. Prodi S-1 Ilmu dan Teknologi Lingkungan. Fakultas Sains Dan Teknologi Universitas Airlangga Surabaya Kampus C, Jalan Mulyorejo, Surabaya 60115, Jawa Timur, Indonesia. Berkas Penelitian Hayati: 18 (83-85)

CSIRO (Ocean and Atmosphere Flaship) 2014. Marine Debris sources, distribution and fate of plastic and other refuse - and its impact on ocean and coastal wildlife. www.csiro.au/marinedebris diakses pada pukul 21.38 Wita, tanggal 20 September 2019 
Hetherington J., Leous J., Anziano J., Brockett D., Cherson A., Dean E., Dillon J., Johnson T., Littman M., Lukehart N., Ombac J., Reilly K., 2005. The Marine Debris Research, Prevention and Reduction Act: A Policy Analysis. Columbia University New York, New York

Lippiat, S., Opfer, S. and Arthur, C. 2013. Marine Debris and Monitoring Assesment. NOAA.

NOAA. 2016. Marine Debris Impacts on Coastal and Benthic Habitats. NOAA Marine Debris Habitat Report.

Nontji, A. 1987. Laut Nusantara. Jakarta.

NybakkenJ. W., 1992. Biologi laut. PT. Gramedia Pustaka Utama. Jakarta
Opfer, S., Arthur, C., and Lippiat, S. 2012. Marine Debris Shoreline Survey Field Guide. NOAA.

Renwarin A., Rogi O.A.H., Sela R.L.E., 2002. Studi Identifikasi Sistem Pengelolaan Sampah Permukiman Di Wilayah Pesisir Kota Manado. Jurnal. Program Studi Perencanaan Wilayah dan Kota, Universitas Sam Ratulangi. Manado Timur, Indonesia. Berkas Penelitian Hayati: 18 (83-85) Timur, Indonesia. Berkas Penelitian Hayati: 18 (83-85)

Wang J., Tan Z., Qiu Q., Li M., 2016. The behaviors of microplastics in the marine environment. Faculty of Chemical Engineering and Light Industry, Guangdong University of Technology, China. Atlas of Science. 